\title{
THE EFFECT OF FOETAL ACIDOSIS ON BUPIVACAINE LEVELS IN UTERO
}

\author{
Brian Pickering, Diane Biehl and Robert Meatherall
}

\begin{abstract}
A mide local anaesthetics are weak bases with $\mathrm{pK}$ 's of 7.80 or greater. Therefore, tissue acidosis may result in ionization and "trapping" of the basic local anaesthetics. The following study was done in the pregnant ewe to determine if the highly protein-bound local anaesthetic bupivacaine demonstrates ion-trapping in the acidotic foetus.

Six pregnant ewes of 135 days gestation were prepared surgically with catheters placed in maternal and foetal femoral arteries and veins. Bupivacaine was infused into the maternal femoral vein to maintain a constant concentration. After two hours of bupivacaine infusion the foetus was made acidotic by an infusion of lactic acid for 45 minutes. Then the acidosis was corrected by an infusion of bicarbonate for an additional 45 minutes. Maternal and foetal bupivacaine levels were measured at 15 minute intervals throughout the experiment. The bupivacaine levels in the foetus and the foetal-maternal ratio increased significatnly during the period of foetal acidosis and declined to the control levels when the acidosis was corrected with bicarbonate.

We conclude from this study that foetal acidosis results in ion-trapping of bupivacaine to a significant extent, despite protein binding in the maternal blood.
\end{abstract}

Key Words: Anaesthetics, Local, bupivacaine; Foetus, acidosis.

\section{INTRODUCTION}

THE AMIDE LOCAL ANAESTHETICS are weak bases with $\mathrm{pK}$ values of 7.80 or greater. Ionization of these drugs will depend on both the $\mathrm{pK}$ and the $\mathrm{pH}$ of the surrounding tissues. ${ }^{1} \mathrm{~A}$ decrease in $\mathrm{pH}$ will thus increase the ionization fraction of local anaesthetics. As ionized molecules do not cross cell membranes easily, acidosis may result in accumulation of local anaesthetic in acidotic tissues. This phenomenon is referred to as an ion-trapping effect.

We recently demonstrated that the lidocaine concentration in foetal blood and the foetalmaternal concentration ratio could be increased by foetal acidosis. ${ }^{2}$ We infused lidocaine $(\mathrm{pK}$ 7.86) intravenously to the pregnant ewe and then produced acidosis in the foetus by infusing lactic acid. Acidosis produced an increase in the lidocaine concentration in foetal blood which was reversed by correction of the acidosis.

Bupivacaine (pK 8.10) is more highly proteinbound in maternal plasma ${ }^{3}$ and thus does not

Brian Pickering, M.D., Anaesthesia Resident; Diane Biehl, M.D., F.R.C.P.(C), Assistant Professor; Department of Anaesthesia, University of Manitoba and St. Boniface General Hospital; Robert Meatherall, Ph.D., Department of Biochemistry, St. Boniface General Hospital, Winnipeg, Manitoba.

Supported in part by St. Boniface Research Foundation Grant Number RF79-3 cross the placenta as easily as does lidocaine. The present study was undertaken to determine if foetal acidosis would increase foetal bupivacaine concentration and the foetal-maternal bupivacaine ratio despite protein binding of bupivacaine in the mother.

\section{METHOD}

Studies were done on six pregnant ewes near term (mean gestational age 135 days). All animals underwent preparatory surgical procedures while anaesthetized with halothane in oxygen. Polyvinyl catheters were placed through a groin incision into a maternal femoral artery and vein. One foetal hindlimb was exposed though a small hysterotomy incision. A polyvinyl catheter was inserted into a foetal femoral artery. A femoral venous catheter was inserted for subsequent infusion of lactic acid and sodium bicarbonate. The hysterotomy and abdominal incisions were closed and the animal was allowed to recover for at least 24 hours before a study was done.

During the study, maternal and foetal mean arterial blood pressure and pulse were recorded continuously on a Hewlett-Packard multichannel recorder, Model No. 7758C. Maternal and foetal blood gases and $\mathrm{pH}$ were determined at 15 minute intervals throughout the study. Measurements were made with a Corning blood gas analyser. 
Model No. 165. Arterial blood was drawn at 15 minute intervals from both mother and foetus for measurement of bupivacaine levels using a gas chromatographic method. ${ }^{4}$

Studies were done with the animal awake and standing quietly in her cage. After a control interval of 30 minutes, to insure stability of the animal model, each study consisted of three sequential periods: (1) a maternal bupivacaine infusion period (2) a maternal bupivacaine infusion and foetal acid infusion period, and (3) a maternal bupivacaine and foetal bicarbonate infusion period.

The first period lasted 120 minutes. We infused bupivacaine into the mother at a constant rate of $0.08 \mathrm{mg} \cdot \mathrm{kg}^{-1} / \mathrm{min}$ to establish a steady state. Maternal and foetal arterial bupivacaine levels were measured every 15 minutes. This infusion rate was continued unchanged during the remainder of the experiment.

The second period lasted 45 minutes. We infused 2.5 $\mathrm{M}$ lactic acid in normal saline into the foetus to decrease foetal $\mathrm{pH}$ from a mean of 7.37 $\pm 0.01 \mathrm{~S}$.E. to $7.12 \pm 0.02 \mathrm{~S}$.E. (range 6.96-7.18). The infusion of lactic acid was adjusted by measuring foetal $\mathrm{pH}$ at three to five minute intervals. Maternal and foetal arterial bupivacaine concentrations, blood-gas, and acid-base variables were measured at 15 minute intervals.

The final experimental period lasted $45 \mathrm{~min}$ utes. Sodium bicarbonate $0.1 \mathrm{M}$ was infused into the foetus to return foetal blood $\mathrm{pH}$ to the control values and maintain the $\mathrm{pH}$ in a range of 7.28 7.43. The total volume of bicarbonate infusion was approximately $20 \mathrm{ml}$. The infusion rate was adjusted by measuring foetal blood $\mathrm{pH}$ at three to five minute intervals. Maternal and foetal arterial bupivacaine concentrations and blood gas and acid-base values were measured at 15 minute intervals.

The cardiovascular values during the three periods of the experiment are expressed as percentage change from control values. Blood gas and $\mathrm{pH}$ changes are expressed as absolute changes from the initial control period.

One-way analysis of variance was used to examine the cardiovascular and blood gas data for statistical significance. Foetal-maternal bupivacaine ratios were compared using Students' " $t$ " test for paired data. $\mathrm{P}<0.05$ was considered significant.

\section{RESULTS}

Maternal and foetal blood pressure and pulse

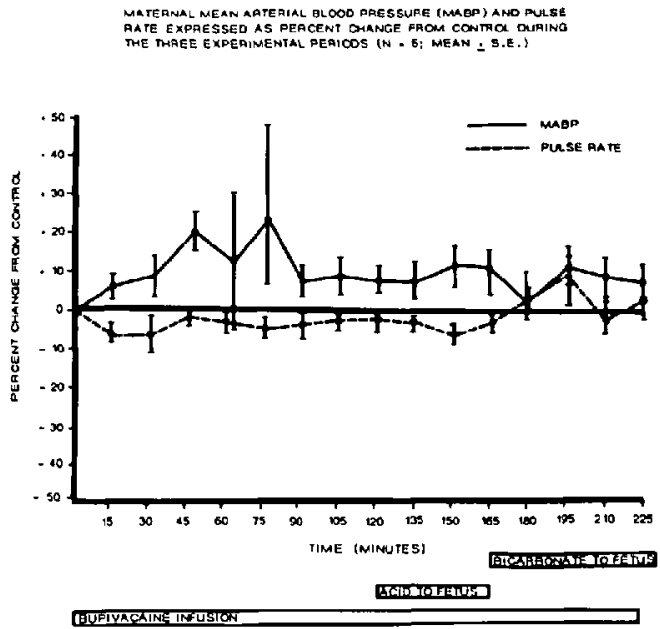

Figure 1 Maternal MABP and pulse rate did not vary significantly during the infusion of bupivacaine at $0.08 \mathrm{mg} \cdot \mathrm{kg}^{-1} / \mathrm{min}$ for 225 minutes.

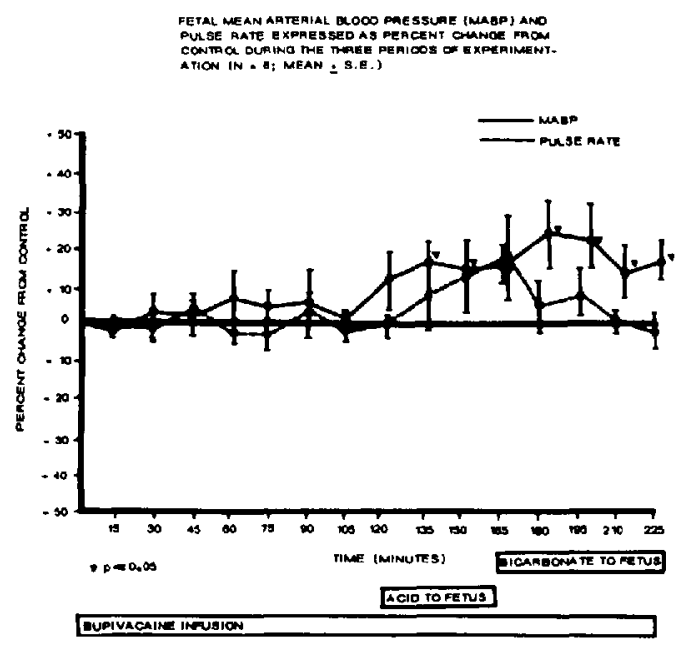

Figure 2 Foetal MABP and pulse rate did not vary significantly from control during the infusion of bupivacaine to the mother, but MABP did rise significantly during the infusion of acid and remained elevated during the bicarbonate infusion.

rate changes from control are shown in Figures 1 and 2. Maternal mean arterial blood pressure (MABP) tended to rise during the infusion of bupivacaine but the increase was not significant. Foetal MAPB rose significantly during the infusion of acid and remained elevated during the remainder of the experiment. There was no significant change in maternal or foetal pulse rate.

The maternal blood gas and $\mathrm{pH}$ results (Table I) showed no significant variation throughout the experiment. Foetal pH remained stable during the infusion of bupivacaine to the mother. With 


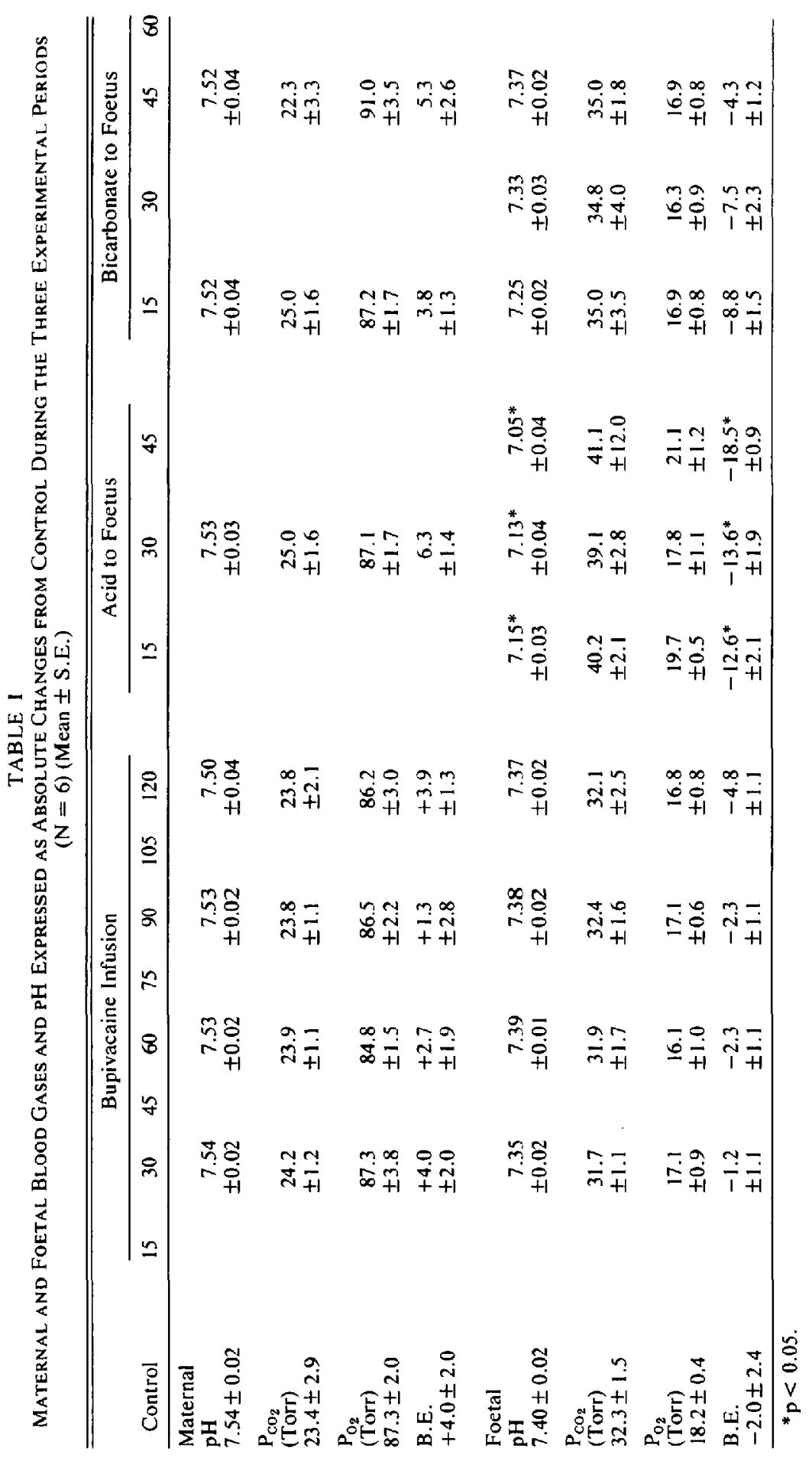




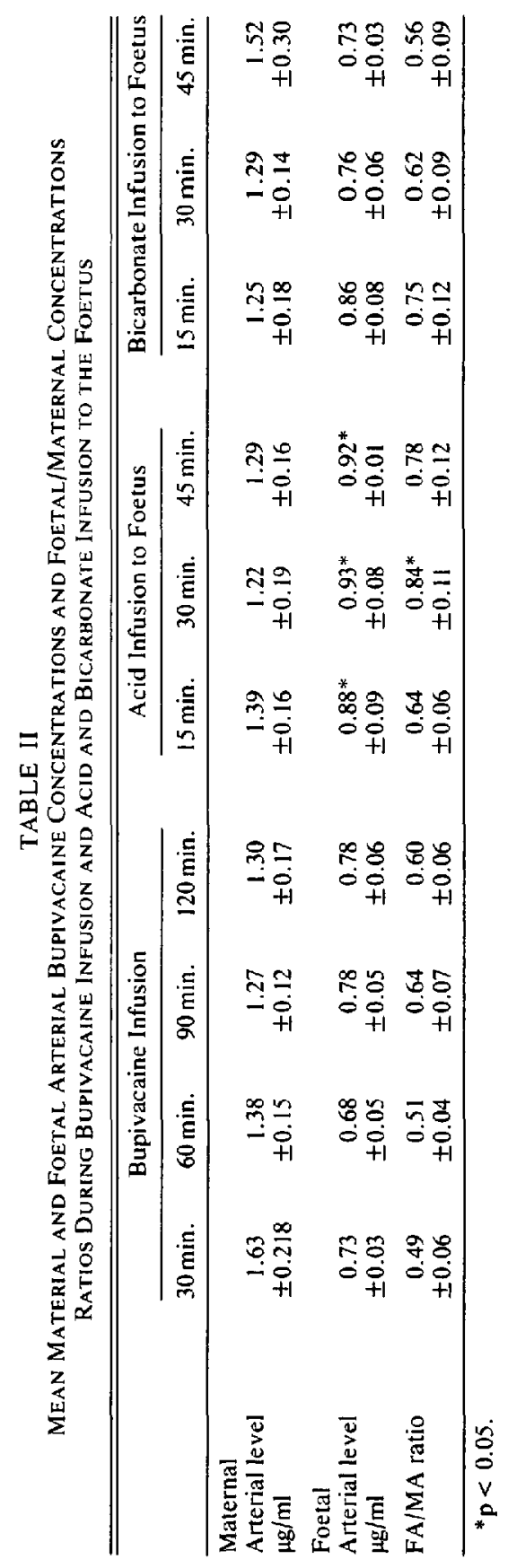


CHANGE OF FAMMA RATIO OF BUPIVACAINE HITH FETAL ACIDOSIS

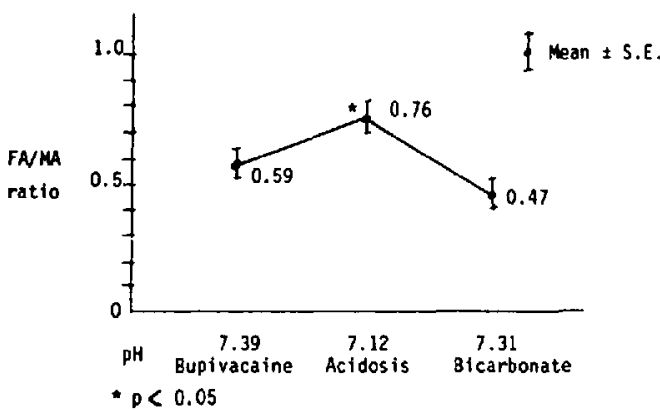

Figure 3 Effect of foetal acidosis is to increase the total foetal concentration and, thus, the FA/MA ratio. Correction of the $\mathrm{pH}$ decreases the ratio.

MATHEMATICAL MODEL OF ION TRAPPING OF BUPIVACAINE USING THE HENOERSON-HASSALBACH EQUATION

$$
P K_{b}=8.1
$$

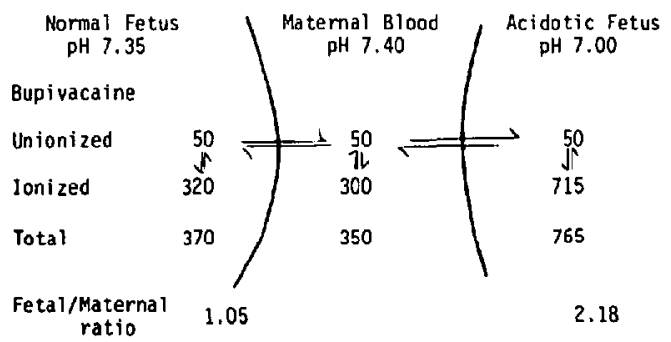

Figure 4 Calculation of theoretical increase of the ionized fraction of local anaesthesia with a $\mathrm{pH}$ decrease according to the formula $\mathrm{pH}=\mathrm{pK}_{\mathrm{b}}+\log$ (nonionized) $1 /$ (ionized).

the infusion of lactic acid the mean $\mathrm{pH}$ decrease was from $7.37 \pm 0.02$ to $7.11 \pm 0.02$. This was returned to $7.32 \pm 0.02$ with the infusion of bicarbonate. The foetal $\mathrm{PCO}_{2}$ also tended to increase with the lactic acid infusion but did not reach the level of significance. Foetal $\mathrm{PO}_{2}$ remained stable throughout the experiment.

Table II shows the maternal and foetal arterial bupivacaine levels and the ratio of foetal to maternal arterial concentration (FA/MA). Maternal levels did not vary significantly during the experiment but the foetal arterial concentration rose significantly during the infusion of acid to the foetus as did the FA/MA ratio. With correction of foetal $\mathrm{pH}$ the arterial levels of bupivacaine in the foetus and the FA/MA ratio declined to control values (Figure 1).

\section{Discussion}

In this study, the mean FA/MA ratio for bupivacaine was $0.59 \pm 0.04 \mathrm{~S}$.E. during the period of constant infusion of bupivacaine to the mother. When the foetus became acidotic, the levels of bupivacaine in the foetal arterial blood rose. The most likely explanation for this is that with a decrease in foetal $\mathrm{pH}$ the ratio of ionized to non-ionized molecules increases. The ionized bupivacaine does not cross the placenta easily and therefore becomes trapped in the foetal circulation, increasing the total concentration. With correction of the acidosis and decreasing the ionized fraction of bupivacaine, the total concentration of bupivacaine in the foetal circulation decreases. The theoretical mathematical model of this explanation is shown in Figure 2.

The protein binding of bupivacaine in the maternal plasma whch is thought to decrease placental transfer of this drug did not significantly alter the effect of $\mathrm{pH}$ changes in the experimental situation. There are possible explanations for this. The first is that protein binding in the sheep may not be as significant as in human plasma. Morishima, et al. ${ }^{7.8}$ have shown previously that protein binding of amide local anaesthetics in other species is similar to that in man, so that the lack of protein binding is unlikely. The other explanation is that protein binding is readily reversible and dependent on the relationship of bound to unbound drug. With alterations in $\mathrm{pH}$ on the foetal side of the placenta more unbound drug transfers from the maternal side. This then changes the relationship between bound and unbound drug in the maternal plasma. The result of this is to release more of the protein bound bupivacaine.

As bupivacaine appears to be as affected by $\mathrm{pH}$ changes as lidocaine, foetal blood levels during acidosis may increase in the clinical situation as well. Therefore, it would seem prudent in the clinical situation to use amide local anaesthetics with care if foetal distress and possible acidosis is diagnosed or suspected.

\section{ACKNOWLEDGEMENTS}

Our thanks are due to Dr. John Wade for reviewing the manuscript, to Ms. M. Cumming and Mr. W. Pucci for technical assistance, and to Mrs. B. Fewster for preparation of the manuscript.

\section{REFERENCES}

1. De Jong, R.H. Physiology and pharmacology of local anesthetics. Illinois, Charles Thomas Publishing Company, pp. 63-84 (1970).

2. BIEHL, D., et al. Placental Transfer of Lidocaine: 
Effects of Fetal Acidosis. Anesthesiology 48: 409 (1978).

3. TuCKer, C.T. \& Mather, L.E. Pharmokinetics of local anesthetic agents. British J. Anaes. 47: 215 (1975).

4. Asling, J.H., ShNider, S.M. Wilkinson, C.R., et al. Gas chromatographic determination of mepivacaine in capillary blood. Anesthesiology $31: 458$ (1969).

5. SCANLON, J.W. Effects of local anesthetics administered to partirient women on the neurological and behavioral performance of newborn children. Bull. N.Y. Acad. Med. 52: 231 (1976).
6. Ralson, D.H. \& Shnider, S.M. The fetal and neonatal effects of regional anesthesia in obstetrics. Anesthesiology 48: 34 (1978).

7. Morishima, H.O., Finster, M., Pedersen, H. et al. Placental transfer and tissue distribution of etidocaine and lidocaine in guinea pigs. Abstracts of Scientific Papers. American Society of Anesthesiologists, p. 83 (1975).

8. Finster, M. \& Pedersen. H. Perinatal pharmacology, ASA Refresher Courses in Anesthesiology 6: 57 (1979)

\section{RÉSUMÉ}

Les anesthétiques locaux à liaison amide sont des bases faibles de pK 7.8 ou plus. II s'ensuit qu'une acidose tissulaire peut favoriser l'ionisation et la séquestration des anesthésiques locaux basiques (on sait qu'une molécule ionisée traverse difficilement les membranes cellulaires).

On a effectué cette étude chez la brebis dans le but de vérifier si la bupivacaïne, anesthésique local hautement lié aux protéines plasmatiques, se comporte selon ce schème. A cette fin, des cathéters ont été placés chirurgicalement dans les veines et les artères maternelles et foetales de six brebis à 135 jours de gestation. Une perfusion de bupivacaïne était ensuite installée dans la veine fémorale maternelle et la perfusion était réglée de façon à maintenir une concentration constante de l'agent anesthésique. Après deux heures de perfusion à la bupivacaine les foetus étaient rendus acidotiques au moyen d'une perfusion d'acide lactique administrée durant 45 minutes. L'acidose était alors corrigée avec une perfusion de bicarbonate étalée de même sur 45 minutes. On mesurait les taux maternels et foetaux de bupivacaïne aux 15 minutes durant toutes la durée de l'expérimentation.

Les taux de bupivacaïne foetaux et les rapports de concentration foetale/concentration maternelle augmentèrent de façon significative durant la phase d'acidose foetale et revinrent aux valeurs de base après correction par le bicarbonate.

Nous concluons que 'acidose foetale déclenche un phénomène d'ionisation-séquestration significatif malgré la forte liaison aux protéines plasmatiques maternelles de la bupivacaine. 